\title{
When the Pandemic Creates Behavioral Changes and Economic Crisis: The COVID-19 Pandemic and the Implications for Policy Making
}

\author{
Ava Chae ${ }^{1}$ and Janet Hanson" \\ ${ }^{1}$ Manhattan High School, Manhattan, KS, USA \\ \#Advisor
}

\section{ABSTRACT}

The COVID-19 pandemic is no longer simply a "health crisis" but seems to have far-reaching impacts and implications as well. The pandemic has led to an unprecedented decline in consumer confidence (demand shock) as people quickly changed their spending behavior to focus on basic needs. In response, the government has taken actions to boost consumer confidence and spending through stimulus packages and other aid. This research uses a public database of private sector data with current information on consumer spending and employment and implements Abraham Maslow's psychological theory, the hierarchy of needs, and Keynesian economics to explain consumer spending behaviors and the U.S. government's response to the pandemic. Three hypotheses are developed and tested using regression analysis. First, the findings of the regression discontinuity show significantly higher spending in industries fulfilling basic needs than in nonessential sectors. Second, a causal relationship was found between aggregate demand, more specifically consumer spending, and employment, revealing the distinctness of the pandemic-caused recession driven by coronavirus fear. The final regression discontinuity was tested to observe the effect of stimulus checks (CARES Act) on spending and economic recovery, revealing positive impacts of boosting aggregate demand. This study provides evidence that while high-income households and individuals were the least impacted by the pandemic regarding employment, they showed the most dramatic changes in spending behavior. The study provides discussions and implications as to how to mitigate the effects of the COVID-19 recession in the U.S.

\section{Introduction}

Virus epidemics and pandemics are not new to the world or to the United States of America. Throughout history, several outbreaks of disease have plagued countries and continents severely disrupting normal life. In 2009, there was an outbreak of the novel H1N1 flu virus (Swine flu) which spread quickly in the U.S. and around the world. This was the first pandemic declared by the World Health Organization (WHO) in 40 years. According to the CDC, there were 60.8 million cases, 274,304 hospitalizations, and 12,469 deaths in the United States (2019). Its socioeconomic losses accounted for 0.5 to 1.5 percent of GDP in affected countries ("The Cost of Swine Flu," 2009). However, the COVID19 pandemic has created a new level of public fear and uncertainty of the future as it has caused unprecedented damage to families and society.

As of January 16, 2021, there have been over 400,000 deaths reported in the United States alone (Dong et al., 2020). The COVID-19 pandemic's devastating impacts are not only on healthcare systems, but also on education, psychology, and the economy. There are reports of a mental health crisis, increasing rates of suicide, food insecurity and hunger, and a rise in inequality, among others (Lund et al., 2020). These consequences are inter-related. The crisis initially caused by the novel COVID-19 virus does not remain simply as a "health crisis" anymore but seems to have far-reaching impacts and implications as well. 


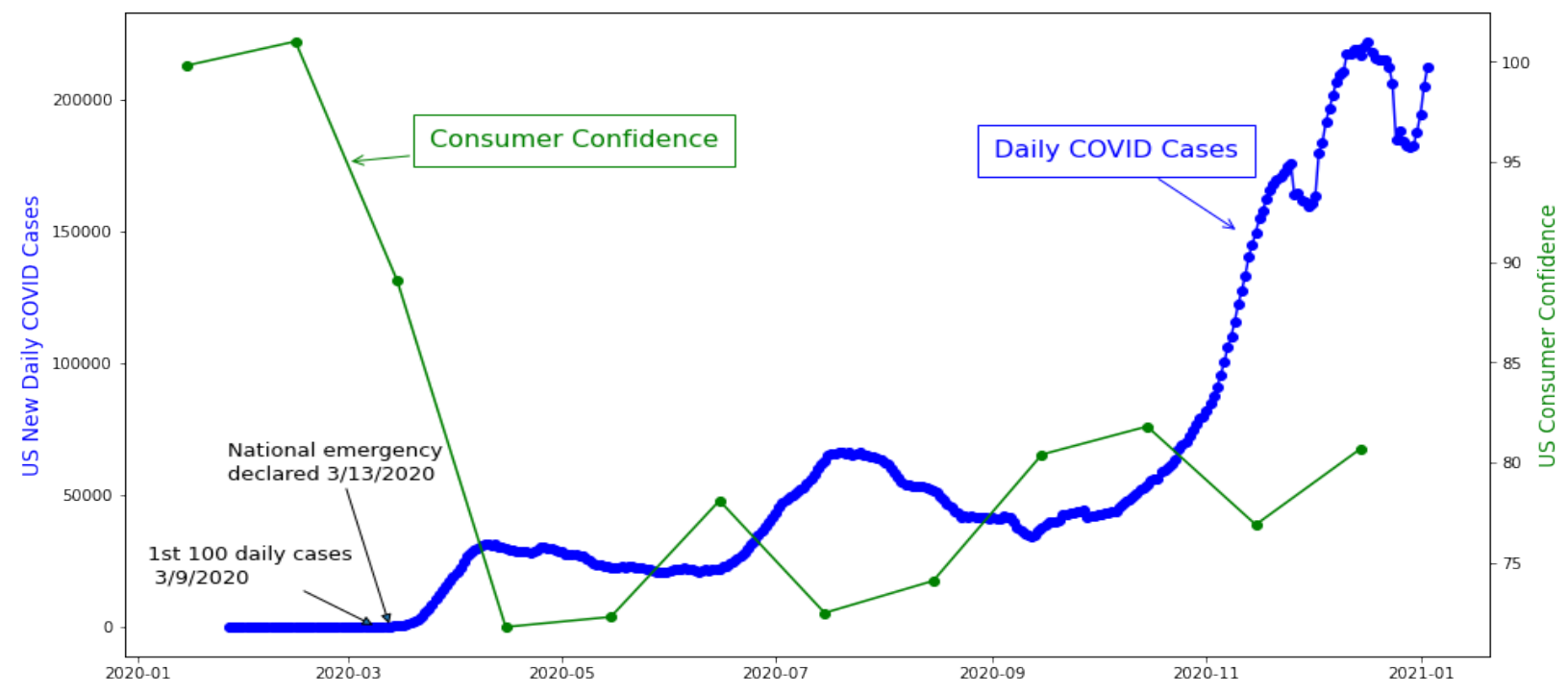

Figure 1 U.S. Daily COVID-19 Cases \& U.S. Consumer Confidence

This research closely observes the pandemic's effect on consumer confidence and spending behavior and its spillover effects on macroeconomic indicators such as unemployment. Fear of virus and uncertainty of future health concerns have changed people's behaviors and there is increasing evidence that one area of behavioral change is how money is spent. At the beginning of the pandemic, when the U.S. government declared a national emergency on March 13th, 2020 (Figure 1), there were reports about stockpiling of items such as toilet paper, disinfecting wipes, hand sanitizer, and bottled water (J.P. Morgan, 2020). Also, people tended to avoid non-essential spending such as dining out, entertainment, and travel. Overall, these changes in behaviors have reduced consumer spending significantly, resulting in layoffs, business closures, and other societal effects going beyond those of a typical health crisis (Gallant et al., 2020). In response, the government has taken actions to boost consumer confidence and spending through stimulus packages (Gerstein, 2020).

Two theoretical frameworks are drawn in this research: Maslow's hierarchy of needs and Keynesian theory of economics. The first is a psychological theory recognizing that people have varied needs and that their basic needs include food, water, personal safety, and health (McLeod, 2007). According to this theory, the basic needs tend to be prioritized before other types of needs such as friendship, sense of connection, status, and recognition. The hierarchy of needs is used to explain the shifts in how people spend money. The latter is a demand-side economic theory focusing on the importance of aggregate demand (or the sum of spending) for the economy and emphasizing the active role of government during an economic recession (Blinder, 2008). This economic theory helps explain the U.S. government's responses to the pandemic through stimulus packages and analyzes whether such policies were effective. Hypotheses about the relationships among consumer spending, unemployment, and government intervention were developed in this research. The hypotheses are tested using data on U.S. consumer spending and unemployment from a public database developed by a group of economists and policy analysts housed at Harvard (Chetty et al., 2020).

\section{Literature Review \& Hypothesis Development}

\section{Maslow's Psychological Theory}

The psychologist Abraham Maslow suggested that there are different categories of human needs and that these needs are hierarchically structured. This is known as the "hierarchy of needs." According to his theory, there are five layers of needs; the most basic level being associated with human physiology (Table 1). The biological requirements for 
human survival are the most important and until they are met, other needs are pushed back. The second most necessary need is safety in the form of shelter, stability, law, and order. The third level of the hierarchy is love and belongingness needs. Humans need interpersonal relationships and social activity that invoke feelings of love and belonging. The fourth human need is esteem. The esteem need is fulfilled with esteem for oneself and respect from others. The last level on the top of the hierarchy of needs is self-actualization (McLeod, 2007). Maslow theorizes that in order for humans to seek and desire to grow "to become everything one is capable of becoming," basic human needs must first be fulfilled (Maslow, 1943).

Table 1 Maslow's Hierarchy of Needs

\begin{tabular}{|l|l|}
\hline Level & Human Needs \\
\hline 5 & Self-fulfillment \\
\hline 4 & Esteem (status, recognition) \\
\hline 3 & Social (love, family, community) \\
\hline 2 & Safety (security, stability, order) \\
\hline 1 & Physiological (water, food, shelter) \\
\hline
\end{tabular}

This theory was developed in the1940s and is applicable now, given the pandemic and people's changing behavior, especially in spending (Abulof, 2017). Recent studies indicate that consumer confidence has dropped sharply since March 2020, and household consumption has become increasingly precautionary and remained focused on essential items and activities. According to J.P. Morgan, people have changed their spending habits as a result of the COVID-19 pandemic (2020). Panic buying of certain household and personal safety items persisted during the early period of the pandemic and consumer spending remained depressed months after the national lockdown. People and families were precautionary when spending money and their consumption was focused on meeting largely physiological needs and safety needs as outlined in Maslow's hierarchy of needs. This change in spending habits created a sharp decline in aggregate demand, which lead to other societal effects as layoffs, business closures, and loss of family income (Lund et al., 2020).

\section{Keynesian Economics}

As a demand-side theory, Keynesian economics focuses on aggregate demand and its role in the health of an economy. When aggregate demand is low, the economic situation moves downward showing signs of low employment. Simply put, reduced demand means a weak economy and is a sign of bigger challenges ahead (e.g., depression). In response, the theory supports the idea of government intervention to boost growth and lessen the impact of recessions. Through changes in public expenditures and tax policies, the government can indirectly influence the demand for goods and services (Blinder, 2008). Keynes first introduced this theory in response to the Great Depression in 1935 and while it was controversial and received little support at first, Keynesian economic models are widely used now, due to their success in prior financial crises (Gordon, 1990).

Specific active fiscal policies that Keynes advocates for are reductions in interest rates and increased government investment in infrastructure. The theory also argues for expansionary fiscal policy to increase net public spending and investment and consumption by the government to raise demand for businesses' products and unemployment (Keynes, 1924). The solution to an economic recession is to shift the aggregate demand curve upward with fiscal and monetary policies (Figure 2), such as income aids and uncertainty reduction (e.g., stimulus packages). In the graphs below, the point of effective demand (E) represents the point when the aggregate demand function (ADF) equals the aggregate supply function (ASF). L represents labor, while Lf marks the available labor force. According to Keynes, government policies are needed to push ADF up to reach full employment (Gordon, 1990). 

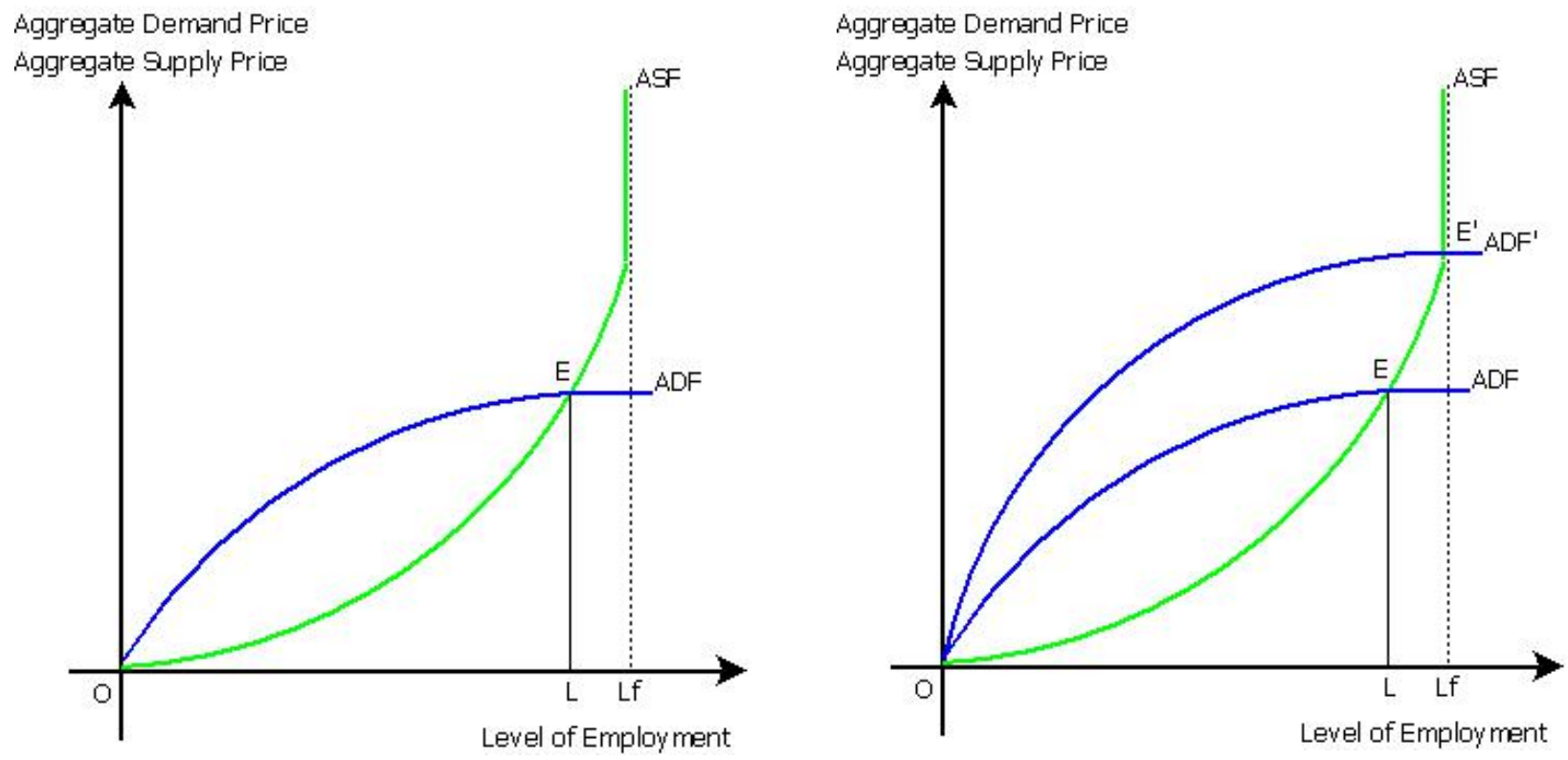

Figure 2 Aggregate Demand and Supply Before and After Fiscal and Monetary Policy

\section{Hypotheses}

The COVID-19 health crisis has led to the sudden rise of fear and uncertainty of the future. This has created a demand shock (weak aggregate demand), which has caused the current economic crisis in the U.S. (Brinca et al., 2020). As per Maslow's hierarchy of needs, consumers will attempt to meet their basic needs first, including physiological requirements and personal safety, especially during times of uncertainty. As a result, the demand for products and services related to basic needs will likely remain strong, while overall household spending is expected to decline. Similarly, in 2006, the US Congressional Budget Office (CBO) developed a pandemic scenario: CBO wrote, “... there is little historical evidence available ..." to estimate the impact of a pandemic on demands and estimated that "...demand would fall off by 80 percent (for three months) in the entertainment, arts, recreation, lodging, and restaurant industries" (Holtz-Eakin, 2005).

In turn, the low demand for goods and services caused layoffs and even business closures on a large scale. As per the Keynesian theory of economics, low aggregate demand is a sign of an economic recession and leads to downward changes in macroeconomic indicators such as employment. The businesses and service industries that are less related to basic needs are expected to experience greater challenges than others. This trend has been particularly severe in industries such as hospitality, entertainment, and recreation (Lund et al., 2020).

The Keynesian theory also argues that during an economic recession, government intervention is necessary to boost demand and lower unemployment, consequently leading to economic recovery (Blinder, 2008). The government has several policy options to boost aggregate demand. The first is to provide more income to households. Another option is to reduce uncertainty caused by the COVID-19 virus by directly addressing the health crisis via vaccinations. Related to the former, the US government passed five major coronavirus relief bills in 2020, amounting to about $\$ 3.5$ trillion of aid to businesses and individuals. The Coronavirus Aid, Relief, and Economic Security (CARES) Act, the largest relief package, totaling nearly \$2 trillion, was passed on March 27, 2020 (Parrot et al., 2020). Among other aids, the legislation included one-time stimulus payments to taxpayers.

Largely drawing upon the perspectives of Maslow's hierarchy of needs and the Keynesian theory of economics on the pandemic, the following hypotheses were developed: 
Hypothesis 1: Consumer spending will focus on basic needs rather than others, which will reduce the overall spending level in the US.

Hypothesis 2: The pandemic caused a demand shock and a decline in spending, leading to downward trends in employment.

Hypothesis 3: The U.S. government intervention (e.g., stimulus checks) is expected to increase consumer confidence and spending.

\section{Research Methodology}

\section{Data}

Because the effects of the COVID-19 pandemic developed quickly, frequently updated national data since the beginning of the pandemic is needed. Also, to test the aforementioned hypotheses, a dataset that includes daily-level information on COVID-19 rates, employment, and consumer spending was desired for fine-grained analysis.

This research relies on a public database of private sector data compiled to provide current information on employment, consumer spending, business revenue, and mobility. The data is compiled by a team of researchers and policy analysts based at Harvard University (Chetty et al., 2020) The data provided is updated frequently to reflect current trends and is grouped into various categories including income level, type of industry, and geographic area. Thus, the public database is suitable for this research, as it satisfies the previously mentioned conditions for testing the research hypotheses.

Consumer spending and employment levels were the main focus of this research. Data on daily consumer spending (March 13 - December 6, 2020) consists primarily of seasonally adjusted credit and debit card spending data, provided by Affinity Solutions, an intelligence platform that uses consumer data to provide solutions to marketers, financial agencies, and other organizations. Spending transactions are categorized by merchant codes to determine the specific industry (e.g. grocery, transportation, etc.) and by consumer zip codes to classify income levels. Income categories were constructed based on the median household income of zip codes, data gathered by the American Community Survey (Chetty et al., 2020). The three income categories: low, middle, and high, are classified by median household income of less than $\$ 46,000$ per year, $\$ 46,000$ to $\$ 78,000$, and greater than $\$ 78,000$, respectively.

Daily employment levels (March 13 - December 6, 2020) were collected from Paychex, Intuit, Earnin, and Kronos. Paychex and Intuit provided firm-level payroll data, while worker-level earnings and timesheet data were collected from Earnin and Kronos, respectively (Chetty et al., 2020). Similar to consumer spending data, employment was broken down into wage and industry categories.

\section{Analysis of Data}

Hypothesis \#1 was tested using the spending data. Especially, the analysis focused on how the U.S. population has spent in two industries: grocery/food and arts/entertainment. These two industries represent the basic needs and the non-based basic ones, respectively, in the hierarchy of needs. The analysis relied on the regression method called "regression discontinuity." Regression discontinuity measures the impact of a treatment on a variable by comparing observations before and after a major event or treatment (Imbens \& Lemieux, 2008). Here, the U.S. government's declaration of a national emergency on March 13th is considered the treatment. The hypothesis assumes that spending on basic needs (e.g., grocery, food) would remain strong, while the consumption of other needs (e.g., arts, entertainment) would significantly decline.

Regression discontinuity is usually approached using non-parametric and parametric estimation techniques. In this research, non-parametric estimation, the more common of the two methods, is implemented. The experimental design is meant to observe treatment effects in data where randomization is not possible (Imbens \& Lemieux, 2008). 
While it is meant to observe causation and determine the impact of a treatment, regression discontinuity cannot be used to declare true causality due to potential confounding variables. In the basic regression discontinuity equation shown in (1), $\mathrm{D}$ is the binary treatment variable for the assignment variable, $\mathrm{x}$.

$$
y_{i}=a+\tau D_{i}+\beta x_{i}+e_{i}
$$

For hypothesis \#2, it is necessary to test whether future unemployment levels can be predicted by consumer spending levels. A statistical analysis called "Granger Causality" was conducted to determine if there is enough evidence to show that the increase in unemployment was caused by less consumer spending, a demand shock (Diks \& Panchenko, 2006). In two time series (consumer spending, unemployment), causality is proven when the consumer spending time series can predict the unemployment time series more accurately than previous employment levels alone.

Granger Causality is generally tested for linear regression in which two variables X1 and X2 create a bivariate linear autoregressive model as seen in (2) and (3). The application of this test assumes covariance stationary; however, both time series (consumer spending and unemployment) were non-stationary (Seth, 2007). Thus, the test was done using a windowing technique in which first differences between data points were processed as locally stationary segments.

$$
\begin{aligned}
& X_{1}(t)=\sum_{j=1}^{p} A_{11 j} X_{1}(t-j)+\sum_{j=1}^{p} A_{12 j} X_{2}(t-j)+E_{1}(t) \\
& X_{2}(t)=\sum_{j=1}^{p} A_{21 j} X_{1}(t-j)+\sum_{j=1}^{p} A_{22 j} X_{2}(t-j)+E_{2}(t)
\end{aligned}
$$

Finally, hypothesis \#3 was also tested using regression discontinuity. The analysis tests whether stimulus checks (part of the CARES Act) significantly increased consumer spending (or aggregate demand), which is expected to alleviate unemployment.

\section{Results and Findings}

Figure 3 shows the trends of consumer spending in six industries between January and December 2020. The spending data is seasonally adjusted credit/debit card spending relative to January 4-31, 2020. The grocery and food spending shows a huge spike (a 60 percent increase) right after the national emergency declaration (March 13) and a strong trend for the rest of the year. On the other hand, the other five industry sectors show a deep hole in March and a recovery trend. In particular, the art and entertainment industry spending appears to be 50-60 percent less than the typical period (January). 


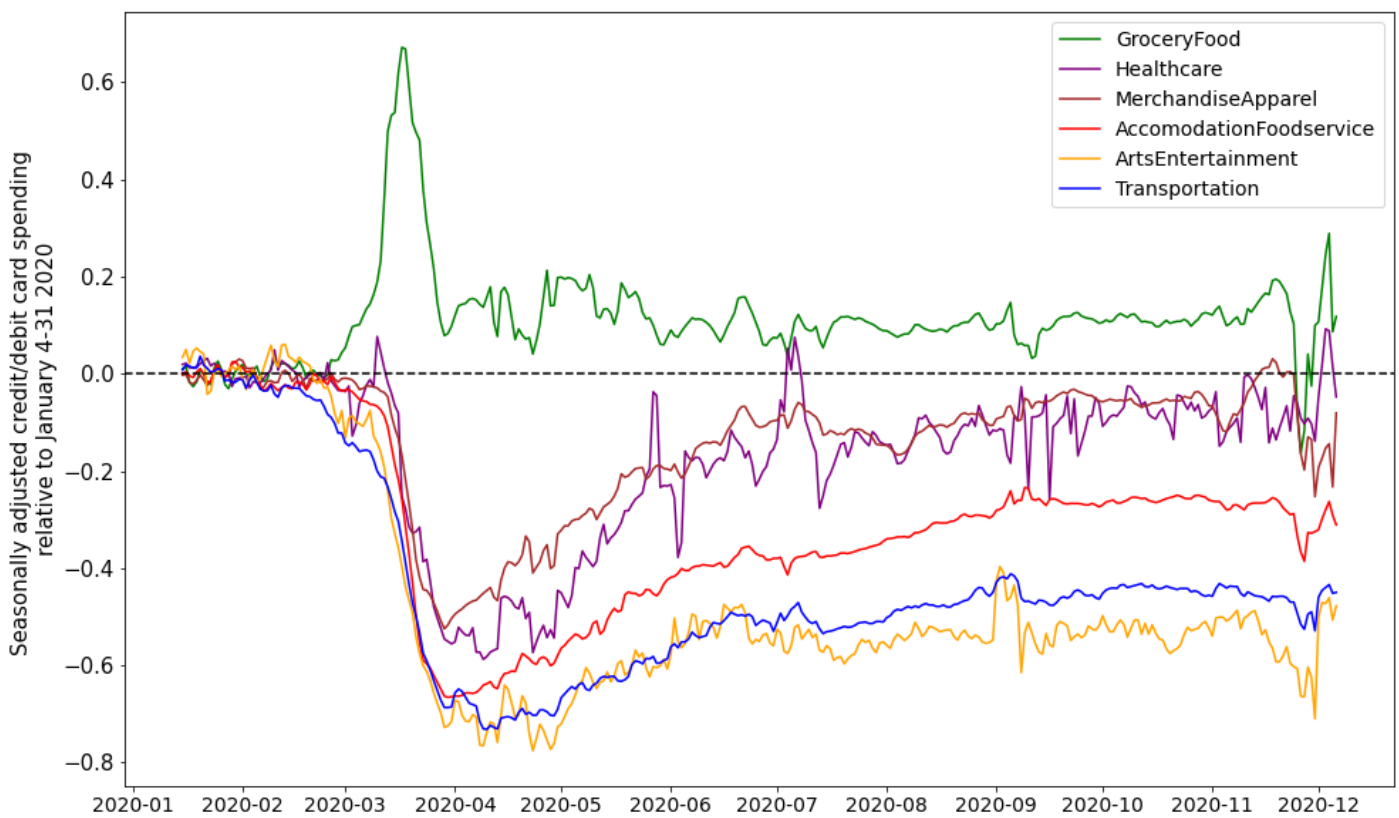

Figure 3 Consumer Spending in Different Industries in 2020

For the regression discontinuity analysis, the time series of two sectors-grocery/food and arts/entertainment-were split into "before" $(2 / 10-3 / 12)$ and "after" $(3 / 13-4 / 13)$ the declaration of a national emergency on March $13^{\text {th }}$. The distribution of spending in two sectors for the two time periods is presented in Figure 4. After the national emergency declaration caused by COVID-19, there was more spending on grocery/food and less on arts/entertainment.

Grocery/Food

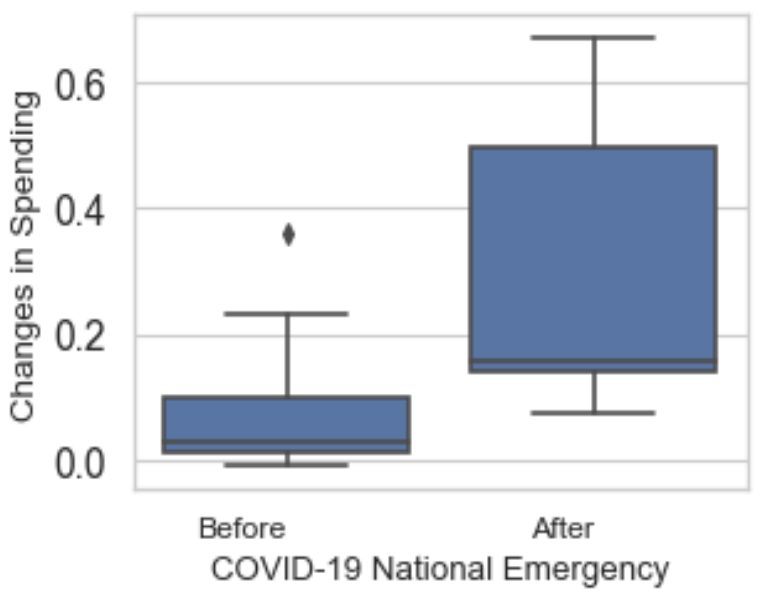

Arts/Entertainment

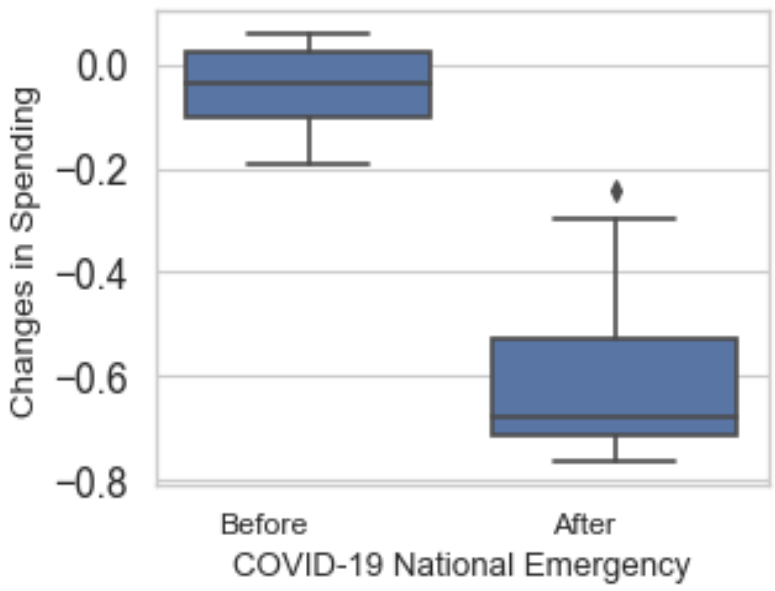

Figure 4 Distribution of Spending Before and After the National Emergency Declaration: Grocery/Food \& Arts/Entertainment

Note. The national emergency was declared on March $13^{\text {th }}$."Before" refers to February $10^{\text {th }}$ - March $12^{\text {th }}$ while "After" refers to March $13^{\text {th }}$ - April $13^{\text {th }}$.

The above trend was statistically tested using the regression discontinuity. Table 2 reports the results of the regression discontinuity. It shows that there is a statistically significant difference in spending between the two sectors, 
as spending on basic needs (grocery/food) went up while the arts/entertainment sector suffered a dramatic decline in spending.

Table 2 Regression Discontinuity Results: Grocery/Food and Arts/Entertainment

\begin{tabular}{|l|l|l|l|l|l|l|}
\hline & Coefficient & St. Dev. & $\mathrm{t}$-value & $\mathrm{p}>|\mathrm{t}|$ & {$[0.025$} & $0.975]$ \\
\hline $\begin{array}{l}\text { Grocery } \\
\text { Food }\end{array}$ & 0.2208 & 0.039 & 5.687 & 0.000 & 0.143 & 0.298 \\
\hline $\begin{array}{l}\text { Arts } \\
\text { Entertainment }\end{array}$ & -0.5646 & 0.030 & -19.114 & 0.000 & -0.624 & -0.506 \\
\hline
\end{tabular}

Hypothesis 2 tests the effects of weak aggregate demand on employment. The Granger Causality test is summarized in Table 3. The results ( $\mathrm{p}$-value $=0.001$ at lag 2 ) show sufficient evidence to support Hypothesis \#2, indicating the strong correlation between consumer spending and employment levels during the pandemic-caused recession.

Table 3 Results of the Granger Causality Test: Consumer Spending and Employment

\begin{tabular}{|l|l|l|}
\hline Number of Lags & F-test & P-value \\
\hline 2 & 7.0257 & 0.0011 \\
\hline
\end{tabular}

Figure 5 plots the changes in spending and employment relative to January 2020. The sudden drop in spending in March 2020 is followed by a similar decline in employment days after. The trend of increased spending from April through the rest of the year also reflects the employment levels from May onward.

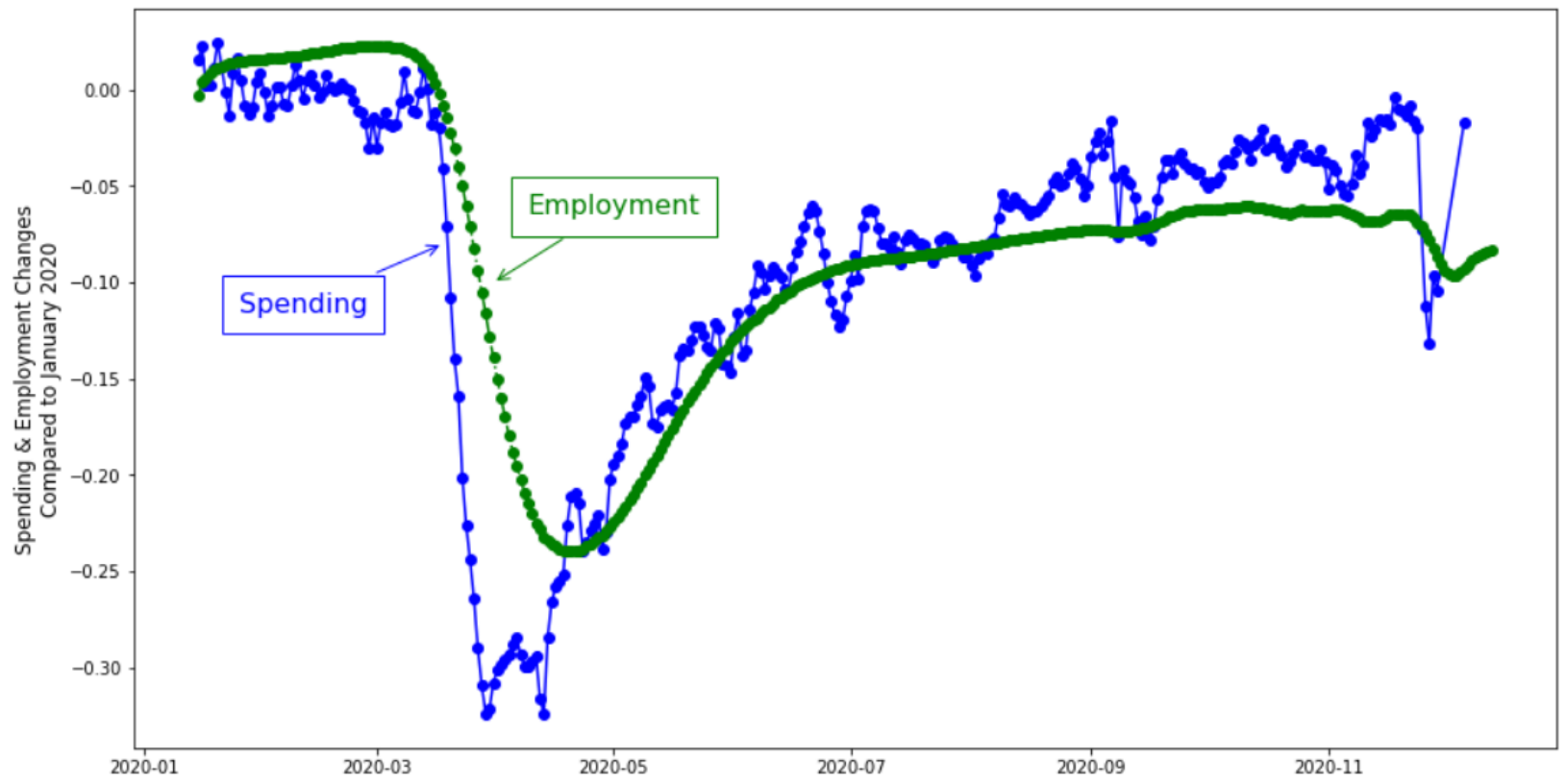

Figure 5 Consumer Spending and Employment Levels in 2020

Hypothesis \#3 tested the effect of the CARES Act and, more specifically, one-time stimulus checks, on consumer spending. The checks were delivered by April 15, 2020, so two time series ( 2 weeks prior to and following April 15) were prepared. The regression discontinuity measured if there is statistically significant discontinuity in consumer spending. Figure 6 shows the substantial increase in consumer spending following April 15. 


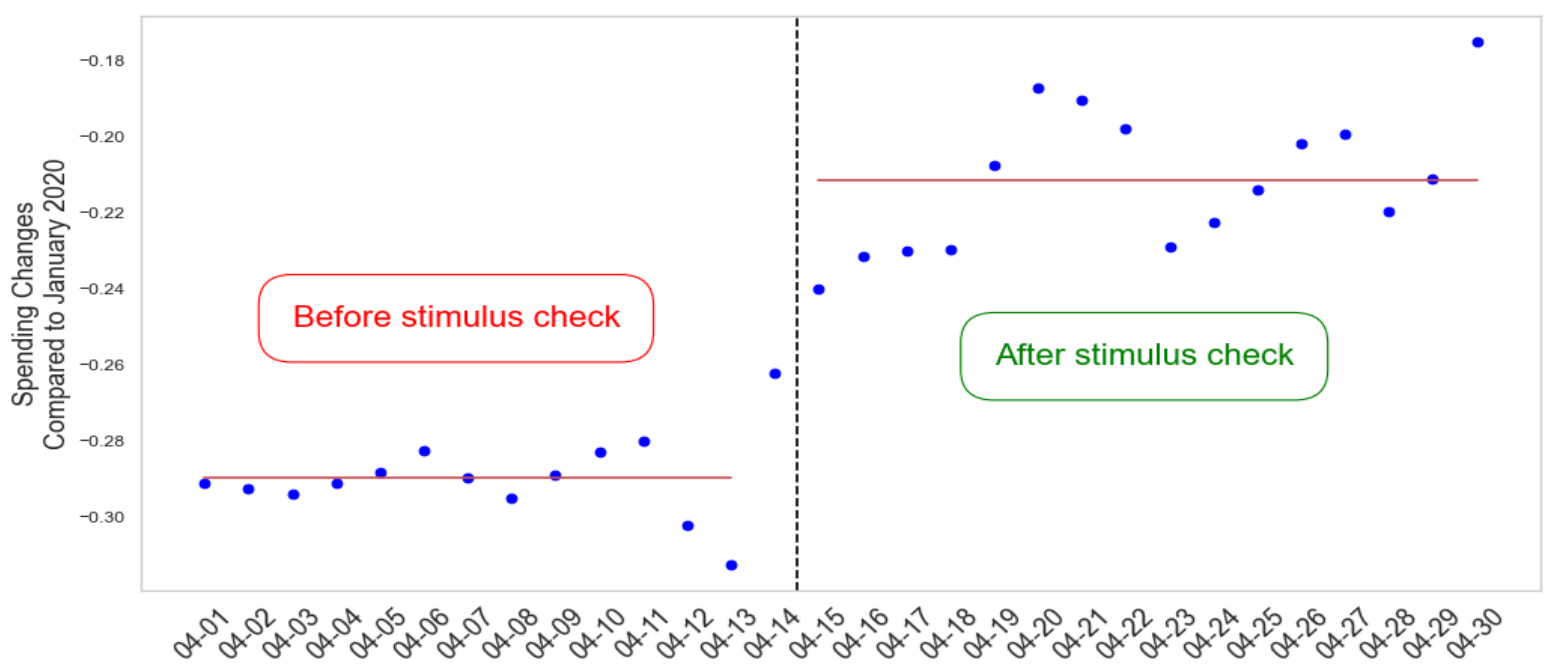

Figure 6 Consumer Spending Before and After Stimulus Checks

The results of the regression discontinuity model, displayed in Table 4, reveal a significant difference before and after the arrival of the stimulus checks $(\mathrm{p}$-value $=0.000)$.

Table 4 Regression Discontinuity Results: Stimulus Checks

\begin{tabular}{|l|l|l|l|l|l|l|}
\hline & Coefficient & St. Dev. & t-value & $\mathrm{p}>|\mathrm{t}|$ & {$[0.025$} & $0.975]$ \\
\hline $\begin{array}{l}\text { Stimulus Ef- } \\
\text { fect }\end{array}$ & 0.0779 & 0.006 & 13.597 & 0.000 & 0.066 & 0.090 \\
\hline
\end{tabular}

Finally, the effect of stimulus checks was examined in terms of industry sectors and income groups. Figures 7 and 8 illustrate changes in spending after the stimulus checks for industries and income levels, respectively. Table 5 shows the results of the regression discontinuity. Three industry sectors show an increase in spending (accommodation/food service $\mathrm{p}=0.000$; merchandise/apparel $\mathrm{p}=0.000$; healthcare $\mathrm{p}=0.002$ ). All three income groups demonstrated significantly more spending after the checks arrived. However, the significance level is higher for low-income people than for those in middle and high income. Despite the extremely low rates of spending in high-income households, data shows that they are the least impacted with regard to employment rates, revealing the discrepancy between different income levels (Figure 9). 
Table 5 Regression Discontinuity Results: Stimulus Effect on Industry and Income

\begin{tabular}{|l|l|l|l|l|l|l|}
\hline & Coefficient & St. Dev. & t-value & $\mathrm{p}>|\mathrm{t}|$ & {$[0.025$} & $0.975]$ \\
\hline Accommodation/Food Service & 0.0549 & 0.005 & 11.956 & 0.000 & 0.045 & 0.064 \\
\hline Arts/Entertainment & 0.0020 & 0.014 & 0.143 & 0.887 & -0.026 & 0.030 \\
\hline Merchandise Apparel & 0.0863 & 0.008 & 10.399 & 0.000 & 0.069 & 0.103 \\
\hline Grocery Food & -0.0221 & 0.015 & -1.438 & 0.162 & -0.054 & 0.009 \\
\hline Healthcare & 0.0466 & 0.013 & 3.455 & 0.002 & 0.019 & 0.074 \\
\hline Transportation & -0.0044 & 0.008 & -0.540 & 0.593 & -0.021 & 0.012 \\
\hline $\begin{array}{l}\text { Low Income } \\
<\$ 46,000\end{array}$ & 0.1025 & 0.007 & 13.756 & 0.000 & 0.087 & 0.118 \\
\hline $\begin{array}{l}\text { Middle Income } \\
\$ 46,000-\$ 78,000\end{array}$ & 0.0711 & 0.006 & 12.591 & 0.000 & 0.060 & 0.083 \\
\hline $\begin{array}{l}\text { High Income } \\
>\$ 78,000\end{array}$ & 0.0381 & 0.006 & 6.477 & 0.000 & 0.026 & 0.050 \\
\hline
\end{tabular}

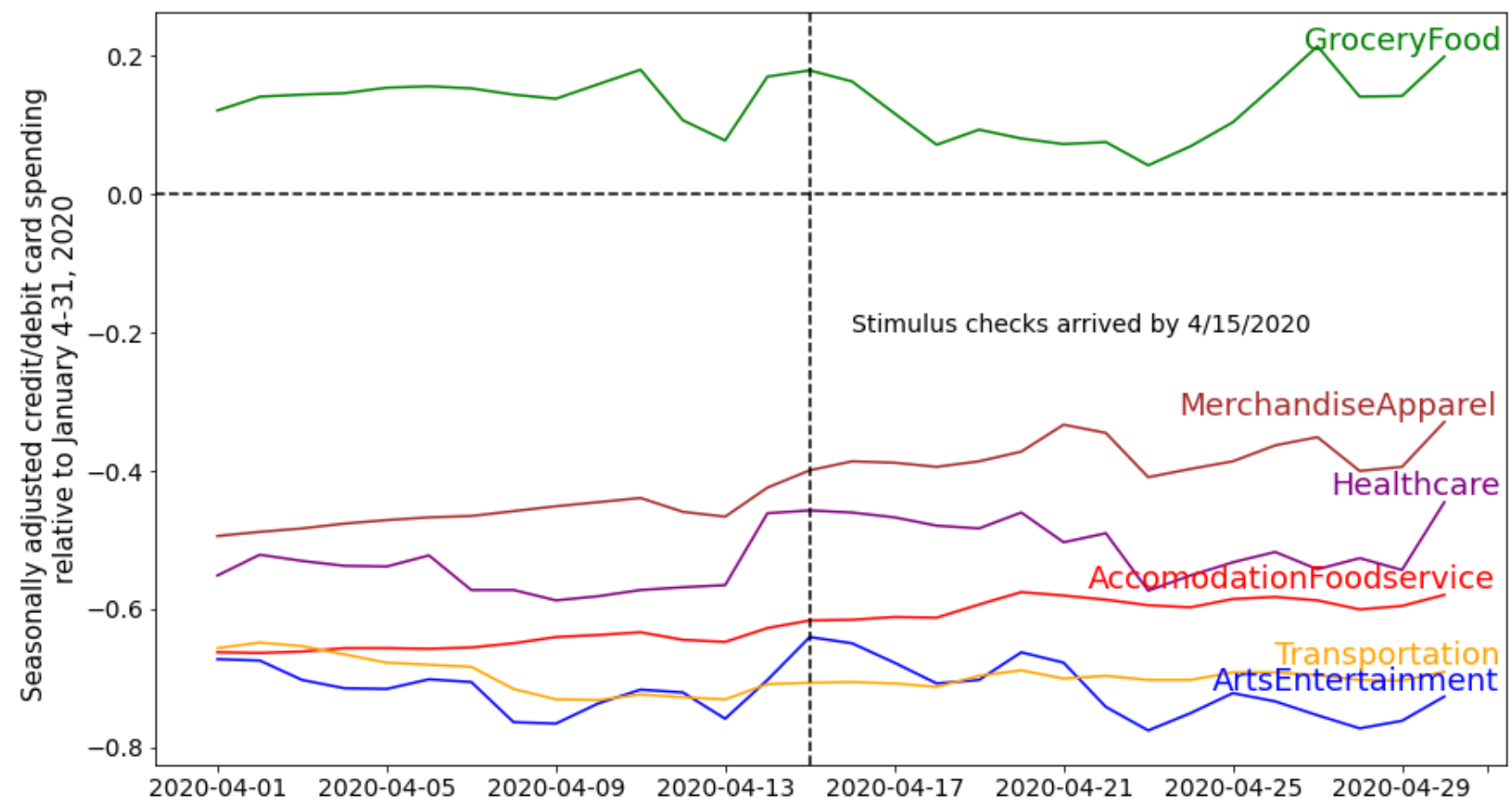

Figure 7 Changes in Spending After Stimulus Checks (by Industry) 


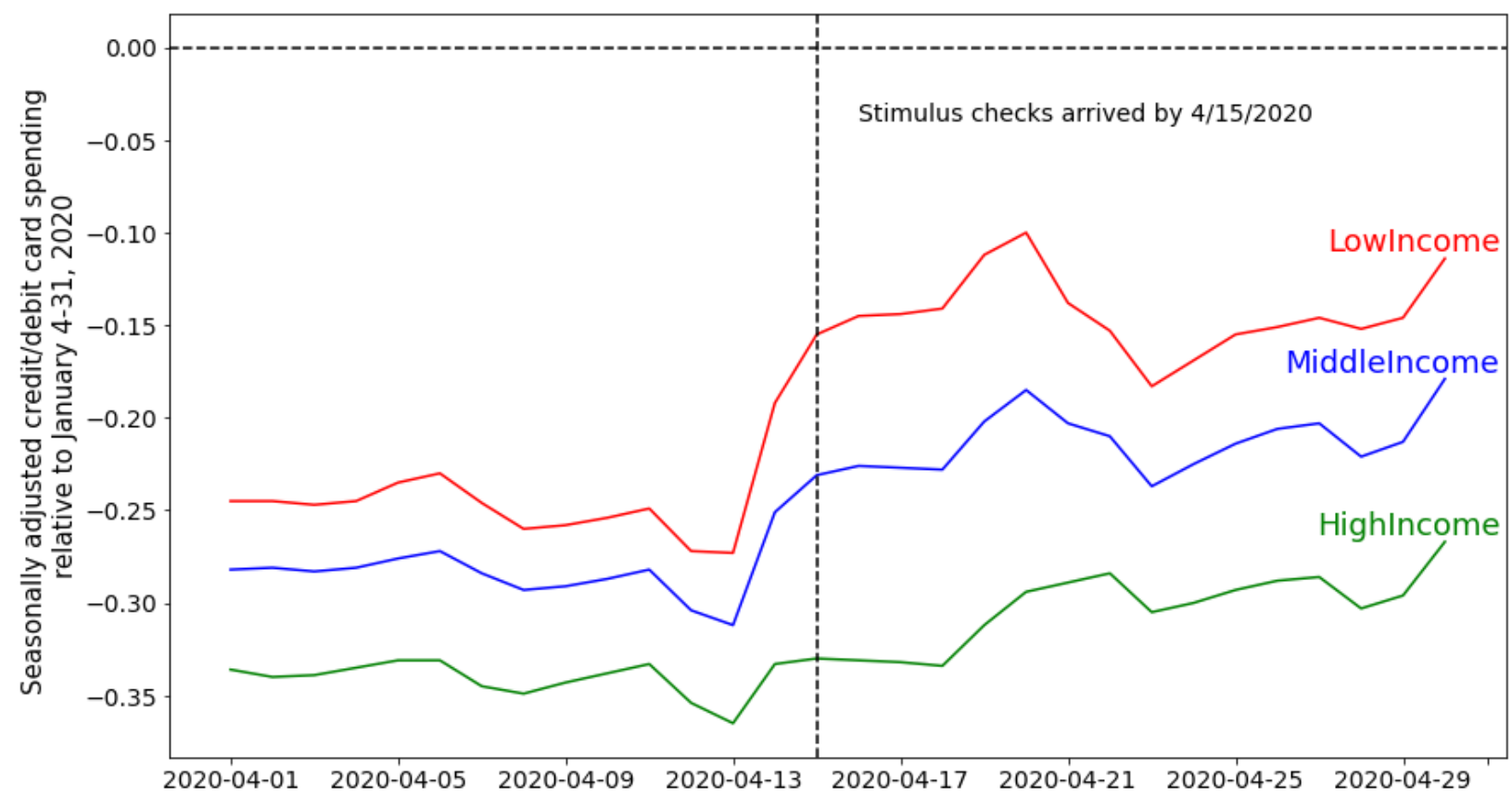

Figure 8 Changes in Spending After Stimulus Checks (by Income Groups)

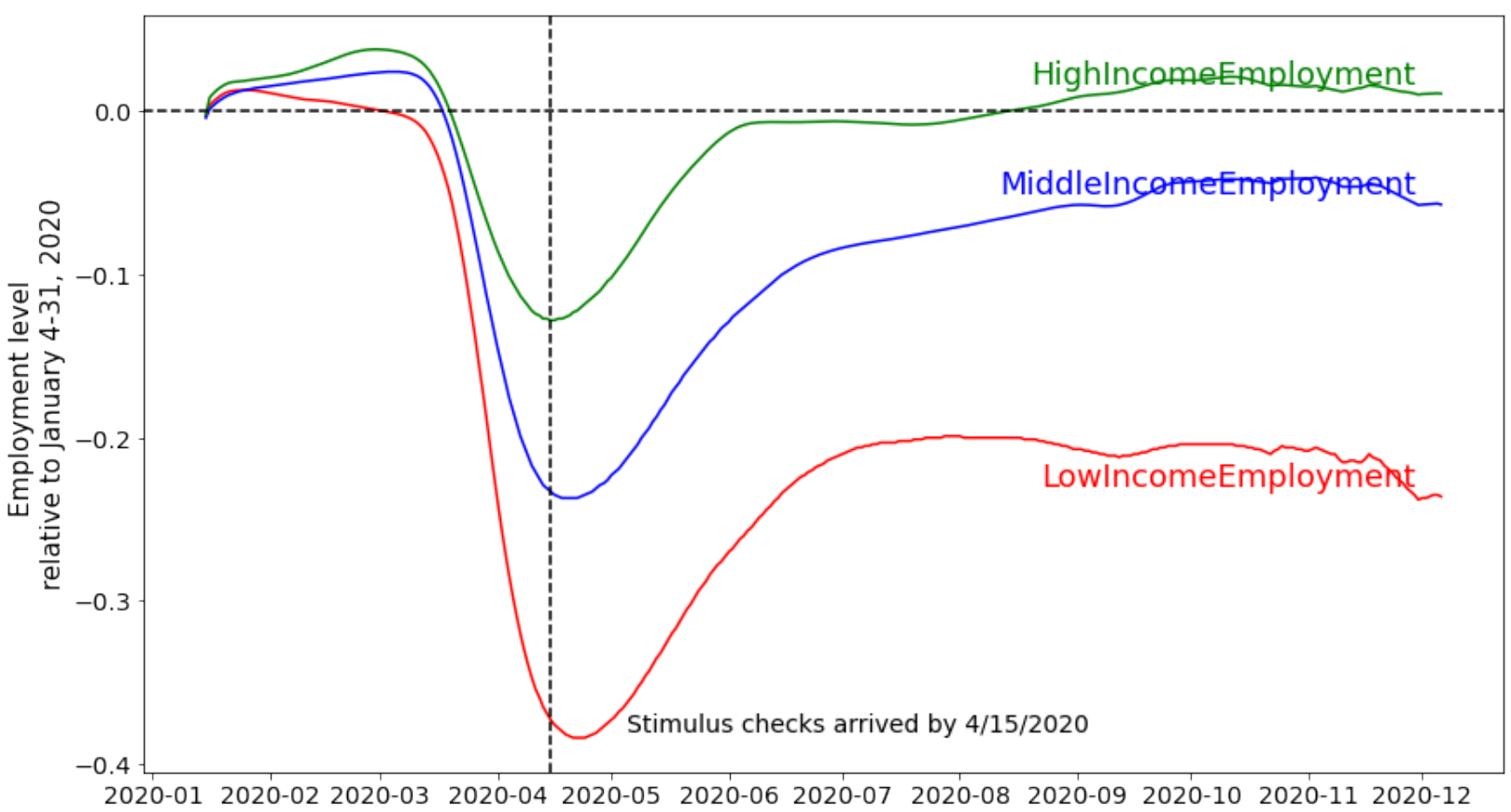

Figure 9 Employment Levels by Income Groups in 2020

\section{Discussion}

The COVID-19 pandemic poses a greater threat than any health crisis the United States has experienced in recent decades. Outbreaks such as the 2003 SARS and 2009 Swine Flu caused national health crises but remained largely under control in the country. However, the COVID-19 pandemic has had far greater impacts: People are not only affected by the virus itself, but by indirect and direct impacts of COVID-19 on other areas of life including job and 
educational sectors. Throughout the country, school districts have closed, businesses have shut down permanently, and mobility has dropped significantly (Lund et al., 2020).

Before the pandemic, consumer confidence was at the highest level since the early 2000s. The economy was in a "Goldilocks" period, with low unemployment, low inflation rates, and strong consumer spending (Bell \& Blanchflower, 2020). The unique combination of supply and demand shocks, particularly the rapid drop in aggregate demand due to coronavirus fears, caused the COVID-19 recession (Brinca et al., 2020). The pandemic-caused changes were sudden and have been on a large scale since the national emergency declaration on March 13, 2020.

The hierarchy of needs can be reflected in consumer spending. Since the beginning of the COVID-19 pandemic and recession, the grocery and food industry was the only sector to see increases in spending in 2020 . Immediately after a national emergency was called in the U.S., all industries showed a plunge in spending, while demand for groceries and food skyrocketed. Also, the healthcare and merchandise/apparel industries recovered much more quickly than the transportation, arts/entertainment, and accommodation industries. By December 2020, spending in healthcare and merchandise had leveled out at around 10 percent lower than most years. However, arts/entertainment and transportation spending remained much lower, at 50 percent less than at the beginning of the year.

Just as the hierarchy of needs suggests, people prioritize their physiological and safety needs over belonging, esteem, and self-actualization needs (McLeod, 2007). During the pandemic and the resulting recession, spending in nonessential industries, such as arts and entertainment, showed significant drops and slow recovery over several months, while industries with fundamental needs, such as food and healthcare, continued to have a steady or even higher demand than during normal times. The regression discontinuity of spending comparing grocery and food to arts and entertainment demonstrates significant differences between the two sectors. Fear of the virus and continuing uncertainty has changed how people behave in spending.

The results of Hypothesis \#2 provide evidence that the COVID-19 health crisis caused a demand shock, and aggregate demand, more specifically consumer spending, had a significant impact on unemployment. While studies recognize the onset of unemployment affecting spending in households and individuals, the results of the Granger Causality test demonstrate the opposite. The steep decline in spending was followed closely by a similar fall in employment levels. This further reveals the distinctness of the pandemic-caused recession against previous economic crises.

As the pandemic has become more than another health crisis, the government's action has focused on two realities_-behavioral science/economics and medicine_through stimulus packages, Operation Warp Speed (OWS), and the Defense Production Act (Gerstein, 2020). The results of Hypothesis \#3 support the role of the government's actions in boosting aggregate demand to lower unemployment. The considerable increase in spending after the arrival of stimulus checks provides evidence that the government intervention resulted in positive outcomes on changing spending behavior.

The results of the regression discontinuity show that the effect of the stimulus checks (CARES Act) is estimated to be an 8 percent increase in spending between April 15th and 30th. Not all industries benefited from this spending increase. Those fulfilling essential goods and services, except grocery/food, were the only ones that showed significant increases in demand. Arts/entertainment and transportation sectors, as expected, did not demonstrate significant increases in spending. Grocery and food, an essential industry, also showed little change from stimulus checks. This is likely due to the already high spending in such areas from the beginning of the pandemic.

When observing the effect of stimulus checks on various income groups, the results indicate significant changes in spending for all income levels. However, spending behaviors of low-income households and individuals ( $<\$ 46,000$ per year) changed more than those of middle and high-income households and individuals. Additionally, while the high-income group was least impacted by the pandemic in terms of employment (and in fact, the group's employment level has been even better than the pre-pandemic period), there was a sharp decline in spending by this group. It is the high-income group that showed the most dramatic behavior in spending after the national emergency and their spending behavior did not change much from stimulus checks. This implies that future stimulus packages should focus on helping those in the low- and middle-income groups, rather than the high-income group. To stimulate 
the spending behavior of the high-income group, the government must directly address their fear of virus through vaccination and other health measures.

\section{Conclusion}

The COVID-19 pandemic is like no other health crisis in recent U.S. history. Its effects are not only found in hospitals and healthcare systems, but also individual families, nursing homes, schools, and businesses. The pandemic has led to an unprecedented level of decline in consumer confidence as people quickly changed their spending behavior to focus on basic needs. This decline is particularly severe among high-income earners and in industries such as arts and entertainment. The pandemic's impact on the low-income group has been devastating, as their employment levels plummeted in the spring of 2020 and have remained very low since then (Gallant et al., 2020). The stimulus checks had substantial effects on increasing spending, but people's focus did not go beyond basic needs (e.g., grocery, food service, healthcare) due to fear of the virus. The high-income group has been impacted least by the pandemic in terms of employment but shows the most significant behavioral changes in spending. Future stimulus packages need to be targeted toward the low- and middle-income groups and the more damaged industries. However, fiscal policy alone does not lead to necessary behavioral changes to restore normality. Medical treatments, vaccination, and other health measures need to be in place to reduce the uncertainty of the future. Maslow's hierarchy of needs and the Keynesian economic theory are valuable for understanding the complexities surrounding human behavior, economic challenges, and the government's roles during the COVID-19 pandemic.

\section{Acknowledgment of Assistance}

The author appreciates Ms. Janet Hanson (Gifted Counselor, Manhattan High School) for sponsoring this research project.

\section{References}

Abulof, U. (2017). Introduction: Why we need Maslow in the twenty-first Century. Society, 54(6), 508-509.

Bell, D. N., \& Blanchflower, D. G. (2020). US and UK labour markets before and during the Covid-19 crash. National Institute Economic Review, 252, R52-R69.

Blinder, A. S. (2008). Keynesian economics. The concise encyclopedia of economics, 2(008).

Brinca, P., Duarte, J. B., \& Faria-e-Castro, M. (2020). Is the COVID-19 pandemic a supply or a demand shock?. Available at SSRN 3612307.

Centers for Disease Control and Prevention. (2019, June 11). 2009 H1N1 Pandemic (H1N1pdm09 virus). https://www.cdc.gov/flu/pandemic-resources/2009-h1n1-pandemic.html.

Chetty, R., Friedman, J., Hendren, N., \& Stepner, M. (2020). The economic impacts of COVID-19: Evidence from a new public database built from private sector data. Opportunity Insights.

Diks, C., \& Panchenko, V. (2006). A new statistic and practical guidelines for nonparametric Granger causality testing. Journal of Economic Dynamics and Control, 30(9-10), 1647-1669.

Dong, E., Du, H., \& Gardner, L. (2020). An interactive web-based dashboard to track COVID-19 in real time. The Lancet infectious diseases, 20(5), 533-534.

Gallant, J., Kroft, K., Lange, F., \& Notowidigdo, M. J. (2020). Temporary unemployment and labor market dynamics during the COVID-19 recession (No. w27924). National Bureau of Economic Research.

Gerstein, D. M. (2020). Assessing the US government response to the coronavirus. Bulletin of the Atomic Scientists, 76(4), 166-174.

Gordon, R. J. (1990). What is new-Keynesian economics?. Journal of Economic Literature, 28(3), $1115-1171$. 
Holtz-Eakin, Douglas. (2005). A Potential Influenza Pandemic: Possible Macroeconomic Effects and Policy Issues. Congressional Budget Office (CBO). https://www.cbo.gov/sites/default/files/109th-congress-20052006/reports/12-08-birdflu.pdf.

Imbens, G. W., \& Lemieux, T. (2008). Regression discontinuity designs: A guide to practice. Journal of econometrics, 142(2), 615-635.

J.P. Morgan. (2020, November 23). How COVID-19 Has Transformed Consumer Spending Habits. https://www.jpmorgan.com/solutions/cib/research/covid-spending-habits.

Keynes, J. M. (1924). The Theory of Money and the Foreign Exchanges. A Tract on Monetary Reform.

Lund, S., Ellingrud, K., Hancock, B., Manyika, J., \& Dua, A. (2020). Lives and livelihoods: Assessing the near-term impact of COVID-19 on US workers. McKinsey Global Institute.

https://www.mckinsey.com/industries/public-sector/ourinsights/lives-and-livelihoods-assessingthe-near-term-impact-of-covid-19-on-us-workers.

Maslow, A. H. (1943). A theory of human motivation. Psychological review, 50(4), 370-396.

McLeod, S. (2007). Maslow's hierarchy of needs. Simply psychology, 1, 1-8.

Parrott, S., Stone, C., Huang, C. C., Leachman, M., Bailey, P., Aron-Dine, A., ... \& Pavetti, L. (2020). CARES Act Includes Essential Measures to Respond to Public Health, Economic Crises, But More Will Be Needed. Center on Budget and Policy Priorities.

Seth, Anil. (2007). Granger causality. Scholarpedia, 2(7):1667.

The Cost of Swine Flu. (2009, July 29). The Economist.

https://www.economist.com/news/2009/07/27/the-cost-of-swine-flu. 